\title{
Characterisation of Serbian durum wheat genotypes based on UPOV-defined characteristics
}

\author{
Verica Takač* · Sanja Mikić · Milan Mirosavljević · Vojislava Momčilović · Dragana Trkulja · \\ Ankica Kondić-Špika · Ljiljana Brbaklić
}

Institute of Field and Vegetable Crops, Maksima Gorkog 30, 21000 Novi Sad, Serbia

\begin{abstract}
Summary: Estimation of the level of durum wheat germplasm genetic diversity is important for its classification and efficient use in breeding programmes. The aim of this study was to assess genetic diversity of durum wheat genotypes developed at the Institute of Field and Vegetable Crops in Novi Sad, Serbia, with 26 morphological characteristics based on the International Union for Protection of New Varieties of Plants guidelines. The Shannon diversity index was used as an indicator of morphological diversity and it ranged from 0.283 for glaucosity of lower side of the flag leaf blade and density of hairiness of uppermost node of the culm, to 0.950 for the ear colour, with the mean value of 0.616, indicating a medium to high level of morphological diversity. On average, the diversity was higher for traits relating to generative organs than for those associated with vegetative plant organs. The 21 morphological characteristics were sufficient to distinguish unique profiles of all durum wheat genotypes. The estimation of varietal diversity and identification of morphological characteristics with the highest discriminative power were done by multiple correspondence analysis. The traits that contributed the most to the distinction of genotypes were the ear colouration, length of beak of the lower glume, lower glume shape, ear length of awns at tip relative to ear length and colour of awns. Morphological characterization using the traits with the highest discriminative power could be a useful complementary method for durum wheat germplasm classification and diversity analysis.

Key words: categorical data, characterisation, discriminative power, diversity, durum wheat, morphological characteristics, multiple correspondence analysis, Triticum turgidum subsp. durum, UPOV
\end{abstract}

\section{Introduction}

Durum wheat (Triticum turgidum L. subsp. durum (Desf.) van Slageren) is a tetraploid species that is adapted to the hot and dry conditions of the Mediterranean climate zones, with an annual production of 35-40 million tonnes (Shewry \& Hey, 2015). Spring, winter and facultative forms of durum wheat are produced on around 13.7 million ha around the world (Lantican et al., 2016). Although it is grown on relatively small areas, contributing with $8-10 \%$ to the wheat production worldwide, durum wheat has a very important role in human nutrition and food security (Ammar et al., 2008). In Europe, it is generally used for

Corresponding author:

verica.takac@ifvcns.ns.ac.rs

Acknowledgments:

This study results from the project TR31066 "Modern Breeding of Small Grains for Present and Future Needs" funded by the Ministry of Education, Science and Technological Development of the Republic of Serbia.

Cite this article:

Takač V., Mikić S., Mirosavljević M., Momčilović V., Trkulja D., Kondić-Špika A., Brbaklić Lj. (2019). Characterisation of Serbian durum wheat genotypes based on UPOV-defined characteristics . Ratar. Pourt., 56 (3), 97-102. making pasta and the demands for durum wheat on its market are high, reflected in 8.3 million tonnes imported in 2017/18, mostly in the EU countries (FAO, 2017). Interestingly, over $80 \%$ of the spring durum wheat cultivated in the developing countries consists of semidwarf cultivars bred within one of the global programmes at International Maize and Wheat Improvement Center (CIMMY'T) in Mexico (Lantican et al., 2005).

The durum wheat breeding programmes in Serbia are fewer and considerably smaller in comparison to those of bread wheat (Triticum aestivum L.). Nevertheless, they are important, since a good quality durum wheat variety is essential for the milling and pasta industries in Serbia, as well as worldwide. At the Institute of Field and Vegetable Crops in Novi Sad, the breeding efforts on durum wheat started from the beginning of 1990s (Dencic et al., 2008). Apart from high yields and good quality, the main objectives of the Serbian durum wheat breeding programme are typical for moderate continental climates and comprise increased tolerance to winter hardiness, drought and prevailing diseases and pests (Sieber et al., 2017). Such objectives can be achieved from a detailed understanding of the genetic diversity within collections (Maccaferri et al., 2007). An insight into genetic diversity of durum wheat breeding 
material can help its classification and characterization, understand their relationships and facilitate the choice of parents for making crosses in different breeding strategies (Soriano et al., 2016). However, the exact extent of genetic variation within the durum wheat in Serbia has not so far been sufficiently examined.

A comprehensive morphological characterisation methodology for each cultivated plant or crop group, as defined by the guidelines of the International Union for Protection of New Varieties of Plants (UPOV) and based on distinctness, uniformity and stability (DUS) criteria, is routinely carried out during the official process of variety registration to correctly identify plant varieties and to protect plant breeders' intellectual property rights. These characteristics also proved suitable for investigating genetic variability of bread wheat germplasm (Donini et al., 2000; Rukavina et al., 2017; Petrović et al., 2018), while little has been done to evaluate the genetic diversity of durum wheat cultivars developed in Serbia.

The aim of this study was to assess the level of diversity of the durum wheat genotypes of the Serbian origin, based on its morphological traits, to estimate the suitability of the UPOV-defined characteristics descriptors for classification of the analysed germplasm and to determine most discriminatory UPOV-defined characteristics for its proper description.

\section{Material and Methods}

A set of fifteen durum wheat genotypes were selected for the phenotypic characterisation using UPOV guidelines. The genotypes encompassed four varieties and nine breeders' lines, all developed at the Institute of Field and Vegetable Crops in Novi Sad, Serbia, during the period from 1998 to 2006 (Table 1).
A total of 26 morphological traits were used for characterization of the selected durum wheat genotypes (Table 2) in a field trial at Rimski šančevi $\left(45^{\circ} 20^{\prime} \mathrm{N}, 19^{\circ}\right.$ $51^{\prime} \mathrm{E}, 84 \mathrm{~m}$ a. s. 1.), in the vicinity of Novi Sad. The morphological diversity was determined based on the assessments of these characteristics as described in the guidelines for the conduct of tests for DUS of the International Union for Protection of New Varieties of Plants (UPOV, 2012).

The normalised Shannon diversity index or Shannon equitability index $\left(\mathrm{H}^{\prime}\right)$ was used as a measure of morphological diversity. It was calculated by dividing the Shannon diversity index by the maximum diversity, i.e. the natural logarithm of the number of groups, in order to obtain values in the range between 0 and 1 (Ramezani, 2012). The more evenly the genotypes were distributed among the groups of a morphological characteristic, the higher was its index. The index of 1 denoted that each group of a characteristic had the same frequency.

The multiple correspondence analysis (MCA) or a homogeneity analysis was used to analyse the patterns of variations with categorical data. It minimizes a least squares loss function by using an alternating least squares algorithm. The analysis was performed with the $\mathrm{R}$ package Homals (de Leeuw \& Mair, 2009). The package allows a visual presentation of both genotypes and the categories of all variables in the form of a single plot.

An $\mathrm{R}$ package VarSelLCM was used to determine the most relevant characteristics for clustering the genotypes and select the number of clusters according to the classical information criteria and maximum likelihood estimation. The most relevant characteristics were selected upon their discriminative power indices, defined as a logarithm of the ratio between the probability that the variable was relevant for the clustering, given the best partition, and that the variable was irrelevant for the clustering (Marbac \& Sedki, 2018).

Table 1. The name, improvement level type and year of release of 15 Serbian durum wheat genotypes

\begin{tabular}{cccc}
\hline No. & Genotype & Type & Year of release \\
\hline 1. & Durumko & Variety & 1998 \\
2. & Dušan & Variety & 1998 \\
3. & NSD4/00 & Breeders' line & 2000 \\
4. & NSD11/00 & Breeders' line & 2000 \\
5. & NSD14/00 & Breeders' line & 2000 \\
6. & NSD16/00 & Breeders' line & 2000 \\
7. & Dolap & Variety & 2000 \\
8. & NSD3/03 & Breeders' line & 2003 \\
9. & NSD4/03 & Breeders' line & 2003 \\
10. & NSD7/03 & Breeders' line & 2003 \\
11. & Dur & Variety & 2003 \\
12. & NSD5/04 & Breeders' line & 2004 \\
13. & NSD1/06 & Breeders' line & 2006 \\
14. & NSD2/06 & Breeders' line & 2006 \\
15. & NSD3/06 & Breeders' line & 2006 \\
\hline
\end{tabular}


Table 2. Morphological descriptor characteristics, number of their categories, normalized diversity index ( $\left.\mathrm{H}^{\prime}\right)$ and discriminative power of the characteristics of durum wheat genotypes

\begin{tabular}{|c|c|c|c|c|}
\hline & Characteristic & No of categories & $\mathrm{H}^{\prime}$ index & Discriminative power \\
\hline & Vegetative & & & \\
\hline 1. & Coleoptile: antocyanin coloration & 5 & 0.846 & 4.047 \\
\hline 2. & Plant: growth habit & 5 & 0.530 & -0.905 \\
\hline 3. & Frequency of plants with recurved flag leaves & 5 & 0.577 & -1.079 \\
\hline 4. & Flag leaf: anthocyanin coloration of auricles & 5 & 0.447 & -1.168 \\
\hline 5. & Flag leaf: glaucosity of sheath & 5 & 0.530 & -0.291 \\
\hline 6. & Flag leaf: glaucosity of lower side of leaf blade & 4 & 0.283 & -0.436 \\
\hline 7. & Culm: density of hairiness of uppermost node & 4 & 0.283 & 0.326 \\
\hline 8. & Culm: glaucosity of neck & 5 & 0.301 & -1.716 \\
\hline 9. & Plant: length & 4 & 0.527 & -0.527 \\
\hline \multirow[t]{3}{*}{10.} & Straw: pith in cross section & 3 & 0.629 & -0.686 \\
\hline & Vegetative average & - & 0.495 & -0.244 \\
\hline & Generative & & & \\
\hline 11. & Time of ear emergence & 3 & 0.664 & -1.567 \\
\hline 12. & Ear: glaucosity & 4 & 0.715 & 0.455 \\
\hline 13. & Ear: distribution of awns & 4 & 0.715 & 1.476 \\
\hline 14. & Ear: length of awns at tip relative to ear length & 3 & 0.784 & 5.593 \\
\hline 15. & Lower glume: shape & 3 & 0.784 & 5.635 \\
\hline 16. & Lower glume: shape of shoulder & 5 & 0.649 & 4.462 \\
\hline 17. & Lower glume: width of shoulder & 4 & 0.459 & 3.153 \\
\hline 18. & Lower glume: length of beak & 4 & 0.761 & 6.918 \\
\hline 19. & Lower glume: curvature of beak & 4 & 0.498 & 0.923 \\
\hline 20. & Lower glume: hairiness of external surface & 2 & 0.837 & 3.973 \\
\hline 21. & Awn: colour & 4 & 0.643 & 5.476 \\
\hline 22. & Ear: length (excluding awns) & 3 & 0.629 & 3.875 \\
\hline 23. & Ear: colouration & 3 & 0.950 & 11.371 \\
\hline 24. & Ear: density & 3 & 0.613 & 2.091 \\
\hline 25. & Grain: length of brush hair & 3 & 0.580 & -0.202 \\
\hline \multirow[t]{3}{*}{26.} & Grain: shape & 3 & 0.776 & -1.079 \\
\hline & Generative average & - & 0.691 & 3.285 \\
\hline & Total average & - & 0.616 & 1.928 \\
\hline
\end{tabular}

\section{Results and Discussion}

The diversity index is determined by the number of groups for each UPOV-defined characteristic and evenness in the distribution of genotypes in each group and is used as a general measure of richness. The average value of the normalized Shannon diversity index $\left(\mathrm{H}^{\prime}\right)$ was 0.616 (Table 2). This overall mean was higher than that estimated by Belhadj et al. (2015) on durum wheat from Tunisia and similar to that of Mengistu et al. (2015) on durum wheat landraces in Ethiopia. The highest individual descriptor diversity was found for ear colouration (0.950), while the lowest was determined for glaucosity of lower side of the flag leaf blade and density of hairiness of uppermost node of the culm (0.283). Nine descriptors had diversity index above 0.700 , namely, anthocyanin coloration of the coleoptile, ear glaucosity, distribution of awns, length of awns at the ear tip relative to ear length, shape of the lower glume, beak length of the lower glume, hairiness of external surface of the lower glume, ear coloration and grain shape. High values of $\mathrm{H}^{\prime}$ for ear coloration, grain shape, glume hairiness and beak shape were also determined in different tetraploid wheat germplasm
(Belhadj et al., 2015, Hailu et al., 2010). A wide distribution of variability for ear glaucosity, hairiness of external surface of the lower glume and length of awns at the ear tip relative to ear length found in this study were similar to the findings of Amine et al. (2011) among Tunisian durum wheat landraces.

Considering the classification of the diversity index, as described by Eticha et al. (2005) and where $\mathrm{H}^{\prime} \geq 0.60$ is considered high, $0.40 \leq \mathrm{H}^{\prime} \leq 0.60$ intermediate and $\mathrm{H}^{\prime} \leq 0.40$ low, more than a half of the characteristics analysed in our study were highly diverse (Table 2 ). The low $H^{\prime}$ indicate unequal distribution of different categories of a particular trait. The lowest diversity was found for culm descriptors, moderately high for leaf traits, while the highest values were found for coleoptile and ear descriptors. On average, the diversity was higher for traits relating to generative organs (0.691) than for those associated with vegetative plant organs (0.495). One of the reasons for the presence of high diversity values in a large number of traits could be a rather diverse gene pool used for selecting parents for crossings in the durum breeding programme at the Institute of Field and Vegetable Crops. 


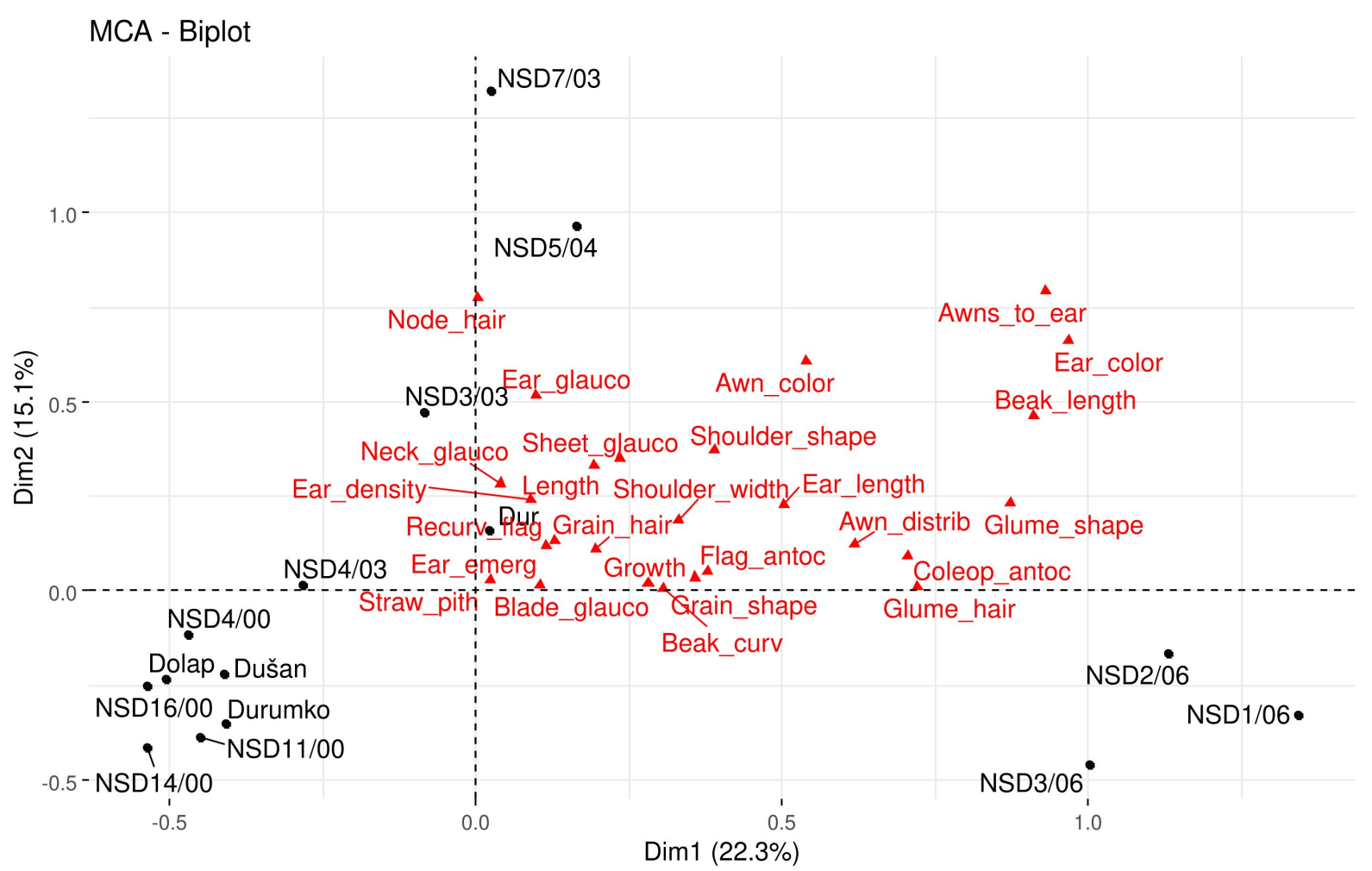

Figure 1. The multiple correspondence analysis of 15 durum wheat genotypes

The number of categories and uniformity of genotype distribution determines discriminative power of descriptors (Hladni et al., 2017). The greatest discriminative power index values had five UPOVbased characteristics, namely, ear colouration (11.371), length of beak of the lower glume (6.918), lower glume shape (5.635), ear length of awns at tip relative to ear length (5.593) and colour of awns (5.476), which more than the other variables distinguished the durum wheat genotypes (Table 2).

The aforementioned characteristics were the variables most relevant for clustering, which points (coordinates) at the multiple correspondence analysis biplot had the longest distances from the origin, indicating their high contribution to the dispersion and grouping of the genotypes (Fig. 1). The multiple correspondence analysis clustered durum wheat in three distinctive groups with genotypes dispersed along both axes, with contribution of the first two dimensions of $38.4 \%$ of the total variability of the categorical data. The model-based clustering according to the Bayesian information criterion (BIC), which had the best score, also confirmed the number of clusters (3) obtained with the multiple correspondence analysis and showed that 15 out of $26(57.7 \%)$ of the variables are relevant for clustering.

The multiple correspondence analysis revealed a diversity pattern of the germplasm with respect to time period of variety release or breeders' lines development.
The first group, consisting of seven durum wheat genotypes developed during the period from 1998 to 2000 , clustered in the third quadrant of the MCA biplot. The second less compacted group encompassed five breeders' lines and varieties from 2003 and 2004, positioned close to the first group. Those breeders' lines and varieties were scattered in the first and the second quadrants. The third group was distributed in the fourth quadrant and contained three breeders' lines that were developed in the latest breeding period (NSD1/06, NSD2/06 and NSD3/06). Similarly, Zarkti et al. (2012) used agro-morphological characters to group 467 durum wheat germplasm according to the period of their release, but also according to the maturing time and plant height. On the contrary, an analysis of temporal trends in diversity of the UK wheat showed overlapping of the diversity using both by molecular and morphological data with only a minor shift of the decadal groups, but it also revealed that the morphological traits exhibited more diversity per morphological characters than the molecular markers (Donini et al., 2000). In the study of Hailu et al. (2010), Ethiopian tetraploid wheat based on phenologic and qualitative traits were clustered 121 genotypes into eight and four groups, based on different criteria, by origin and altitude, respectively, whereas days to heading, hairy glumes, ear type and lower glume shoulder shape were the descriptors that contributed most to their differentiation. 
Five UPOV-based characteristics, such as ear colour, awn colour, length of beak of the lower glume, lower glume shape and ear length of awns at tip relative to ear length, enabled differentiation of genotypes with similar phenotypic attributes. Most of the durum wheat genotypes from the first group were characterised with white ears $(83 \%)$, white awns $(83 \%)$, longer length of awns $(100 \%)$, medium beak length $(67 \%)$ and elongated lower glumes $(83 \%)$, while all the genotypes developed in the latest breeding period had strongly coloured ears, light brown awns, shorter awns, longer beak length and strongly elongated lower glume shape. These imply that during almost of a decade of the durum wheat variety development, different selection criteria and breeders preferences induced, either directly or indirectly, a temporal shift from longer to shorter length of awns at tip relative to ear length, from white to coloured ears and awns, from medium to long beak length of the lower glume and from elongated to strongly elongated lower glume shape. Besides the breeders' selection criteria, one of the additional reasons for such qualitative shifts could also be the introduction of new source of diversity into breeding programs at the Institute of Field and Vegetable Crops, through extensive genetic material exchange with genebanks and breeding institutes. The shifts in the type of diversity that breeders use in their programmes and that are accordingly reflected in commercial varieties have been driven by the constant need to address changing environments using adequate agricultural practices and adaptable crop ideotypes (Chenu et al., 2017; Wang et al., 2019).

\section{Conclusions}

The level of diversity of durum wheat germplasm based on morphological traits was sufficiently high, although a relatively small number of genotypes were analysed. The UPOV-defined characteristics descriptors proved to be suitable for classification of the durum wheat. The most discriminative UPOV-defined characteristics that provided best differentiation among durum wheat germplasm were ear colour, awn colour, length of beak of the lower glume, lower glume shape and ear length of awns at tip relative to ear length. The multiple correspondence analysis gave a good insight into genotype diversity and group homogeneity, enabling differentiation of genotypes with similar phenotypic attributes with the selected optimal descriptors. Morphological characterization can be used to improve description and classification of durum wheat germplasm, and contribute to assessment of a level of genetic diversity, providing valuable information to durum wheat breeders.

\section{References}

Ammar, K., Lage, J., Villegas, D., Crossa, J., Hernandez, H., \& Alvarado, G. (2008). Association among durum wheat international testing sites and trends in yield progress over the last twenty-two years. In International symposium on wheat yield potential: Challenges to international wheat breeding. Mexico: CIMMYT. pp. 108-119.

Amine, S., Sourour, A., Olfa, S.A., Cyrine, R., da Silva, J.A.T., \& Hajer, S.A. (2011). Morphological Diversity of Some Qualitative Traits in Tetraploid Wheat Landrace Populations Collected in the South of Tunisia. International Journal of Plant Breeding, 5(1), 6770

Belhadj, H., Medini, M., Bouhaouel, I., \& Amara, H. (2015). Analyse de la diversitéphénotypique de quelques accessions autochtones de blédur (Triticum turgidum ssp. durum Desf.) du sud tunisien. Journal of New Sciences, Agriculture and Biotechnology, 24(5), 11151125.

Chenu, K., Porter, J. R., Martre, P., Basso, B., Chapman, S. C., Ewert, F., ... \& Asseng, S. (2017). Contribution of Crop Models to Adaptation in Wheat. Trends in Plant Science, 22(6), 472-490. doi:10.1016/j.tplants.2017.02.003

de Leeuw, J., \& Mair, P. (2009). Gifi methods for optimal scaling in R: The package homals. Journal of Statistical Software, 31(4), 1-20. doi:10.18637/jss.v031.i04

Dencic, S., Mladenov, N., Przulj, N., Kobiljski, B., Hristov, N., Momcilovic, V., \& Roncevic R. (2008). 70 years of small grains breeding at Institute of Field and Vegetable Crops in Novi Sad. Zbornik radova Instituta za ratarstvo i pourtarstvo, 45(1), 15-29.

Donini, P., Law, J. R., Koebner, R. M. D., Reeves, J. C., \& Cooke, R. J. (2000). Temporal trends in the diversity of UK wheat. Theoretical and Applied Genetics, 100(6), 912-917. doi:10.1007/s001220051370

Eticha, F., Bekele, E., Belay, G., \& Börner, A. (2005). Phenotypic diversity in tetraploid wheats collected from Bale and Wello regions of Ethiopia. Plant Genetic Resources, 3(1), 35-43. doi:10.1079/pgr200457

Food and Agriculture Organization of the United Nations. (2017). Food Outlook - Biannual Report on Global Food Markets. Rome: FAO. June, 142 pp, http://www.fao.org/3/a-i7343e.pdf.

Hailu, F., Johansson, E., \& Merker, A. (2010). Patterns of phenotypic diversity for phenologic and qualitative traits in Ethiopian tetraploid wheat germplasm. Genetic Resources and Crop Evolution, 57(5), 781-790. doi:10.1007/s10722-009-9518-z

Hladni, N., Terzić, S., Mutavdžić, B., \& Zorić, M. (2017). Classification of confectionary sunflower genotypes based on morphological characters. The Journal of Agricultural Science, 155 (10), 1594-1609. doi:10.1017/s0021859617000739

Lantican, M. A., Dubin, H. J. \& Morris, M. L. (2005). Impacts of International Wheat Breeding Research in the Developing World, 19882002. Mexico, D.F.: CIMMYT.

Lantican, M., Braun, H. J., Payne, T. S., Singh, R. G., Sonder, K., Baum, M., \& Erenstein, O. (2016). Impacts of International Wheat Improvement Research. 1994-2014. Mexico, D.F.: CIMMYT.

Maccaferri, M., Stefanelli, S., Rotondo, F., Tuberosa, R., \& Sanguineti, M. C. (2007). Relationships among durum wheat accessions. I. Comparative analysis of SSR, AFLP, and phenotypic data. Genome, 50(4), 373-384. doi:10.1139/g06-151

Marbac, M., \& Sedki, M. (2018). VarSelLCM: an R/C++ package for variable selection in model-based clustering of mixed-data with missing values. Bioinformatics, 35(7), 1255-1257. doi:10.1093/ bioinformatics/bty786

Mengistu, D. K., Kiros, A. Y., \& Pè, M. E. (2015). Phenotypic diversity in Ethiopian durum wheat (Triticum turgidum var. durum) landraces. The Crop Journal, 3(3), 190-199. doi:10.1016/ j.cj.2015.04.003

Petrović, S., Marić, S., Čupić, T., Rebekić, A., \& Rukavina, I. (2017). Assessment of molecular and phenotypic diversity among winter wheat cultivars. Genetika, 49(2), 583-598. doi:10.2298/ gensr1702583p

Ramezani, H. (2012). A Note on the Normalized Definition of Shannon's Diversity Index in Landscape Pattern Analysis. Environment and Natural Resources Research, 2(4), 54-60. doi:10.5539/enrr.v2n4p54

Rukavina, I., Petrović, S., Čupić, T., Vila, S., Guberac, S., \& Drenjančević, L. (2017). Genetic variability of wheat germplasm represented in the south Pannonian region. Genetika, 49(3), 831842. doi:10.2298/gensr1703831r 
Shewry, P. R., \& Hey, S. (2015). Do “ancient" wheat species differ from modern bread wheat in their contents of bioactive components? Journal of Cereal Science, 65, 236-243. doi:10.1016/ j.jcs.2015.07.014

Sieber, A. N., Longin, C. F. H., \& Würschum, T. (2017). Molecular characterization of winter durum wheat (Triticum durum) based on a genotyping-by-sequencing approach. Plant Genetic Resources, 15 (1), 36-44. doi:10.1017/s1479262115000349

Soriano, J. M., Villegas, D., Aranzana, M. J., del Moral, L. F. G., \& Royo, C. (2016). Genetic Structure of Modern Durum Wheat Cultivars and Mediterranean Landraces Matches with Their Agronomic Performance. PLoS ONE. 11(8), e0160983. doi:10.1371/journal.pone.0160983
UPOV (2012). Guidelines for the Conduct of Tests for Distinctness, Uniformity and Stability: Durum wheat (Triticum turgidum L. subsp. durum (Desf.) Husn.). Switzerland, Geneva: International Union for the Protection of New Varieties of Plants. TG/120/4., Available at: https: //www. upov. int/edocs/tgdocs/en/tg120. pdf.

Wang, B., Feng, P., Chen, C., Liu, D.L., Waters, C., \& Yu, Q. (2019). Designing wheat ideotypes to cope with future changing climate in South-Eastern Australia. Agricultural Systems, 170, 9-18. doi:10.1016/j.agsy.2018.12.005

Zarkti, H., Ouabbou, H., Udupa, S. M., Gaboun, F., \& Hilali, A. (2012). Agro-morphological variability in durum wheat landraces of Morocco. Australian Journal of Crop Science, 6(7), 1172-1178.

\section{Ocena genetičke raznolikosti genotipova tvrde pšenice prema karakteristikama koje je definisao UPOV}

\section{Verica Takač · Sanja Mikić - Milan Mirosavljević · Vojislava Momčilović Dragana Trkulja · Ankica Kondić-Špika · Ljiljana Brbaklić}

Sažetak: Ocena genetičke raznolikosti germplazme tvrde pšenice je važna za njenu klasifikaciju i efikasno korišćenje u oplemenjivačkim programima. Cilj ovog rada bio je da se proceni genetička raznolikost genotipova tvrde pšenice stvorenih u Institutu za ratarstvo i povrtarstvo u Novom Sadu, sa 26 morfoloških osobina prema uputstvu Međunarodne unije za zaštitu novih biljnih sorti (UPOV). Šenonov indeks diverziteta je korišćen kao indikator morfološke raznolikosti i kretao se od 0,283 za prevlaku na rukavcu zastavičara i dlakavosti vršne internodije, do 0,950 za boju klasa. Prosečna vrednost Šenonovog indeksa od 0,616 ukazuje na srednje visok nivo morfološke raznolikosti. U proseku, raznovrsnost je bila veća za osobine koje se odnose na generativne biljne organe nego za vegetativne. Utvrđeno je da je 21 morfološka osobina bila dovoljna za razlikovanje jedinstvenih profila svih genotipova tvrde pšenice. Procena sortne raznolikosti i identifikacija morfoloških osobina sa najvećim diskriminativnim vrednostima je urađena pomoću višestruke korespodentne analize. Osobine koje su najviše doprinele razlikovanju genotipova su bile: boja klasa, dužina zadnje strane glume, oblik donje glume, odnos dužine osja i klasa, kao i boja osja. Morfološka karakterizacija pomoću osobina sa najvećim diskriminativnim vrednostima može biti korisna dopunska metoda za klasifikaciju i analizu diverziteta germplazme tvrde pšenice.

Ključne reči: diskriminativna vrednost, durum pšenica, kategorički podaci, morfološke karakteristike, ocena, raznolikost, Triticum turgidum subsp. durum, UPOV, višestruka korespodentna analiza 